\title{
Spatial variation of chlorophyll integrity in a mangrove plant (Excoecaria agallocha) of Indian Sundarban, with special reference to leaf element and water salinity
}

\author{
Subhajit Bhar ${ }^{1}$, D. Chakraborty ${ }^{1}$, S. S. Ram ${ }^{2}$, D.Das ${ }^{1}$, A. Chakraborty ${ }^{2}$, M. \\ Sudarshan $^{2}$ and S.C. Santra ${ }^{1}$ \\ ${ }^{1}$ Department of Environmental Science, University of Kalyani, India \\ ${ }^{2}$ UGC DAE CSR, Kolkata Centre, India
}

\begin{abstract}
Present study describes a site specific variation of leaf elemental concentration and Photosynthetic pigment concentration in a mangrove plant Excoecaria agallocha in Sundarban, India. Three locations (S1, S2 and S3) were selected according to water salinity gradient in north to southward direction. Range of water salinity is from 19 ppt to 34 ppt. All elements $(\mathrm{Fe}, \mathrm{Cu}$, and $\mathrm{Mn}$ ) are found to be higher in S1 followed by $\mathrm{S} 2$ and $\mathrm{S} 3$ except $\mathrm{Zn}$. They follow the trend like $\mathrm{Fe}>\mathrm{Mn}>\mathrm{Zn}>\mathrm{Cu}$. Interestingly photosynthetic pigment concentration (total chlorophyll, chlorophyll-a, chlorophyll-b) showed negative correlation with salinity i.e. increase in water salinity causes decrease in pigment concentration. Results from our study depicts that Sundarban is facing problems for increasing pollution load and water salinity.
\end{abstract}

Keywords: Excoecaria agallocha, Leaf element, Mangrove, Salinity gradient, The Sundarban.

\section{Introduction}

The Sundarban, a UNESCO World Heritage Site (for rich flora and fauna) covering parts of Bangladesh and Indian state of West Bengal, is the largest single block of tidal halophytic mangrove forest in the world (Gopal and Chauhan, 2006). Mangrove forests are among the most productive ecosystem and are natural renewable resource that grows in saline coastal sediment habitats in the tropics and subtropics (Chapman, 1977; Knox and Miyabera, 1984). Being host for a number of threatened and endangered species, with different animals, mammals, amphibians, reptiles and bird species, they play crucial role for protecting environment from the fury of cyclones and storms and also protect coral reefs, sea-grass bed, shipping lines from siltation. Mangrove vegetation can acts also as a purifier of water by absorbing impurities and harmful heavy metal and also absorbs air pollutants. The mangrove plants show different responses to elemental uptake (Kabata-Pendias and Pendias, 1997).

Flow of anthropogenic activity induced pollutants from nearest metro city Kolkata, population pressure in this region, global warming etc., are now causing threats to this natural resource. One important impact of these disturbances is increase in water salinity (Mitra et al., 2004). Decreasing fresh water amount in the tributaries of river Hooghly, siltation in the river channel directly trigger salinity increase while sea level rise due to Global Warming and increasing evaporation rate, indirectly help to increase the water salinity. Salinity also has some adverse effect on photosynthetic efficiency in the plant (Critchley, 1985; Sharkey et al., 1985). According to Naskar et al., (1997) high salinity and human interference have compelled several species to migrate towards the eastern Sundarban or are gradually dying. In coming future Sundarban will face destruction of major forest resources along with forest environment due to anticipated sea level rise and increasing salinity caused by global warming. It is reported that salinity adversely affects metabolic activities and seedling growth of plants (Hampson and Simpson, 1990; Zidan and Al-Zahran, 1994).

Besides increasing water salinity, heavy metal pollution causes another threat to mangrove ecosystem (Agoramoorthy et al., 2008) as heavy metals are retained in mangrove forests through plant uptake (Machado et al., 2002). Earlier reports of MacFarlane and Burchett (2000) showed that Avicennia marina exposed to zinc, copper, and lead, accumulate high concentration of metals in their cell wall of the roots. The same group has enlightened that Heavy metals are amongst the most serious pollutants within the natural environment due to their toxicity, persistence and bioaccumulation problems (MacFarlane and Burchett, 2000).

The present research was designed to evaluate a site specific variation of chlorophyll integrity and leaf element of Excoecaria agallocha and changes of chlorophyll on the basis of leaf element and salinity gradient. These in turn will the fact, how Sundarban is in risk. 


\subsection{STUDY AREA}

\section{Materials And Methods}

The study areas (Fig.1) are located in an around Sundarban. Study Site I (S1) situated near Matla river $\left(22^{\circ} 18^{\prime} 40.53^{\prime \prime} \mathrm{N} 88^{\circ} 40^{\prime} 31.27^{\prime \prime} \mathrm{E}\right)$ having most population pressure than other two sites. Boat activities were carried out by local fisherman and also ferry service is there. Site II (S2) $\left(22^{\circ} 11^{\prime} 22.51^{\prime \prime} \mathrm{N} 88^{\circ} 41^{\prime} 11.71^{\prime \prime} \mathrm{E}\right)$ situated near river Hariavanga and human population moderate, fishing activity is there. Site III (S3) $\left(21^{\circ} 34^{\prime} 25^{\prime \prime} \mathrm{N}\right.$ $88^{\circ} 17^{\prime} 47^{\prime \prime E}$ ) is situated near the Bay of Bengal; fishing and tourist activity are there. The sites have diverse human interferences with a variable degree of exposure to heavy metal and trace organic contamination. Information's of three study sites are in Table1.

\subsection{STUDY SPECIES}

Excoecaria agallocha is mangrove species belonging to family Euphorbiaceae (Ghani, 2003). It is found near the bank of tidal rivers in brackish water and almost all the places in the above study area of Sundarban. Leaves and saps are used in epilepsy, conjunctivitis dermatitis, haematuria, and leprosy. Sap is used in toothache. This plant provides match wood. Plant also has anti-cancerous, antibacterial and antiviral properties (Peter and Sivasothi. 1999).

\subsection{SAMPLING TECHNIQUES}

The mangrove plant leafs were collected from three sites. For each sampling station, three replicate were taken $(n=3)$. Water sample were also collected from the same sampling sites. The samples were immediately packed with zip-lock packet and labeled. All samples were kept in cooler box with ice at $4^{\circ} \mathrm{C}$ (Prica, 2007) during transporting back to the laboratory at the trace element lab, UGC DAE CSR, Kolkata Centre, India.

\subsection{ELEMENTAL ANALYSIS USING EDXRF}

\subsubsection{SAMPLE PREPARATION}

Leaf samples were lyophilized for $36 \mathrm{~h}$ and dried leaf samples were homogenized using a mortar and pestle and $150 \mathrm{mg}$ sample made into pellets $(1 \mathrm{~mm}$ thick and $13 \mathrm{~mm}$ diameter) using a tabletop pelletizer (Pressure: $100-110 \mathrm{~kg} / \mathrm{cm}^{2}$ for $5 \mathrm{~min}$ ). Three pellets were made for each sampling site.

\subsubsection{EDXRF MEASUREMENT}

EDXRF (Energy Dispersive X-Ray Fluorescence) spectroscopy is a multi-elemental, nondestructive technology use in elemental analysis. The elemental analysis of lichen samples was carried out using a Xenemetrix, Ex-3600 Energy dispersive X-ray fluorescence (EDXRF) spectrophotometer with an oil-cooled Rh anode X-ray tube (maximum voltage $50 \mathrm{kV}$, current $1 \mathrm{~mA}$ ). The measurements were carried out in vacuum environment using different filters (between the source and sample) for optimum detection of elements. A Ti filter (0.05-mm-thick) was used in front of the source for $\mathrm{Mn}, \mathrm{Fe}, \mathrm{Cu}$ and $\mathrm{Zn}$ with an applied voltage of $20 \mathrm{kV}$ and a current $400 \mathrm{~mA}$. All measurements were carried out for $1200 \mathrm{~s}$. The X-rays were detected using a liquidnitrogen-cooled $12.5 \mathrm{~mm} 2 \mathrm{Si}$ (Li) semiconductor detector (resolution $150 \mathrm{eV}$ at $5.9 \mathrm{KeV}$ ). The X-ray fluorescence spectra were quantitatively analyzed by the software nEXT integrated with the system. A standard reference material (SRM) from National Institute of Standards and Technology (NIST) Apple leaf (SRM 1515) was used for quantification of the elements and checking the reliability of the data obtained by the system.

\subsubsection{PIGMENT ANALYSIS}

Pigment analysis was done following methods of Barnes et al. (1992). About 50mg mangrove leaves (E.agallocha) of all three sites were extracted in dark for $1 \mathrm{hr}$ at $65^{\circ} \mathrm{C}$ with $5 \mathrm{ml}$ of di-methyl sulfoxide (DMSO) in the presence of polyvinyl-pyrrolidone (PVP) $\left(2.5 \mathrm{mg} / \mathrm{ml}^{-1}\right)$ to minimize chlorophyll degradation. Extracts were then allowed to cool to ambient temperature, diluted 1:1 with fresh DMSO, and the absorbance were taken at 740 $\mathrm{nm}$, a reflection of turbidity, was checked with a PerkinElmer lambda-25 UV-VIS-spectrophotometer to be certain that it was always less than 0.01 . To assess chlorophylls, absorbance of the extracts was then read at 665 , 649, 435 and $415 \mathrm{~nm}$. Chlorophyll a, Chlorophyll b and total chlorophyll were calculated using equations derived from specific absorption coefficients for pure chlorophyll a and chlorophyll b in DMSO (Barnes et al. 1992).Three replicates were used for each sites. 


\section{Results And Discussion:}

Our results depict a site specific variation of elemental profile as well as photosynthetic pigment analysis (Chlorophyll-a, Chlorophyll-b, Total Chlorophyll) in E. agallocha .Photosynthetic pigment changes with salinity gradient i.e increase in water salinity causes decrease in chlorophyll content in E. agallocha.

Figure2. represents site specific variation of elements $(\mathrm{Mn}, \mathrm{Cu}, \mathrm{Zn}, \mathrm{Fe})$ in leaf of E. agallocha . All elements (except $\mathrm{Zn}$ ) are found to be higher in low saline region (S1) followed by S2 (moderately saline ) and S3 ( high saline). Fe content is higher in all sites than other elements. Interestingly, higher level of variation of $\mathrm{Mn}$ and $\mathrm{Fe}$ are noticed between these three sites. Mn is found to be 35\%-31\% higher in S2 than S3 and S1, while we observed $\mathrm{Fe}$ is $70 \%(\mathrm{~S} 2)$ and $57 \%$ (S3) higher concentration than S1. Pollution load and anthropogenic activities may explain the higher elemental concentration in S1 followed by S2 and S3, while heavy metal pollution like $\mathrm{Zn}$ is found to be higher in S3. Defew et al., (2005) also found same trend $(\mathrm{Fe}>\mathrm{Mn}>\mathrm{Zn}>\mathrm{Cu})$ of elemental concentration in mangrove sediments as well as in mangrove plants. Our results are in tune with Pahalawattaarachchi et al., (2009); they found high Fe content than other metals in Rhizophora mucronata.

Similarly, low saline region (S1) contains higher amount of total chlorophyll which follows site S2 (moderately saline) and S3 (high saline) (Fig.3). S2 contains 10.15\% less total chlorophyll, $9.78 \%$ less chlorophyll a, $11.17 \%$ less chlorophyll b with respect to low saline zone S1. While for S3 (high saline region), it is $19 \%$ less total chlorophyll, $10.15 \%$ less chlorophyll $\mathrm{b}$ and $19.11 \%$ chlorophyll $\mathrm{b}$ than low saline zone S1 (Fig-2). Pearson correlation (Table-2) represents a very strong correlation between pigment concentration (Chla, Chl-b and total chlorophyll) and $\mathrm{Mn}, \mathrm{Zn}$, salinity $(\mathrm{p}<0.001)$ and $\mathrm{Fe}(\mathrm{p}<0.05)$. While against salinity it shows a strong negative correlation. Some elements also show positive correlation between them like $\mathrm{Mn}$ and $\mathrm{Fe}$ ( $\mathrm{p}<0.001), \mathrm{Cu}$ and $\mathrm{Mn}$. According to Dhanapackiam and Muhammed (2010), high salinity (40 and $50 \mathrm{mM})$ induced a significant decreasing effect in the concentration of pigment (chlorophyll a and chlorophyll b) and also in the total chlorophyll concentration with respect to control. Our results also revealed the same trend, which showed that in high saline region (S3), pigment (chlorophyll a and chlorophyll b) concentrations are also low and in low saline region(S1), pigment (chlorophyll a and chlorophyll b) concentration is high. Earlier reports of Biber (2011), also supposed that change in salinity affects photosynthetic pigment of Rhizophora mangle $L$.

\section{Conclusion}

This preliminary study depicts a site specific variation of leaf elemental concentrations as well as photosynthetic pigment analysis of Excoecaria agallocha. Water salinity of these sites are significantly different from one another, that is reflected through variation in chlorophyll concentration (Increase in water salinity causes decrease in chlorophyll content), which signifies salinity causes destruction of chlorophyll (i,e annihilation in photosynthetic activity). Other species also have same photochemical responses on salinity (Naidoo et al., 2002). Whether salinity has any adverse relation with mangrove elemental uptake or not, needs more study, so that these plants can be used for bioremediation purposes. E agallocha of S1 contains higher elemental concentration which signifies higher pollution load than other sites, which may cause further threat to Sundarban. So, proper assessment and mitigation as well as safety measures are urgently needed. The pigments, being the key factors for controlling the growth and survival of the mangroves plants require an optimum salinity range between 4 to 15 psu (Downton 1982; Burchett et al., 1984) for proper functioning. The present study is extremely important from the point of view of rising salinity in this study area of Sundarban where fresh water supply were depleted due to heavy siltation (Chaudhuri and Choudhury, 1994) and sea level rising (Hazra et al., 2002).

\section{Acknowledgements}

Authors are very much thankful to UGC-DAE Consortium for Scientific Research, Kolkata Centre for providing EDXRF facility and fund for carrying out the work. The authors also thankfully acknowledge Govt. College of Engineering and Leather Technology, Kolkata for providing UV-VIS Spectrophotometer. 


\section{Reference}

[1]. A.B. Chaudhuri and A. Choudhury, Mangroves of the Sundarbans, India. (IUCN, 1994) 284

[2]. A. Ghani, Medicinal Plants of Bangladesh (2 nd edition, The Asiatic Society of Bangladesh, 2003) 228-229

[3]. A.H. Collin and M. Watts, Flavor production in culture. in D. A. Evans, W.R. Sharp, P. V. Ammirato, and Y. Yamada, (Eds.) Hand book of plant cell culture. (Macmillan Publishing Company, New York, 1983) 729-747

[4]. A.I. Daniel, Copper enzymes in isolated chloroplasts, poly-phenoloxidase in Beta vulgaris. Plant Physiol. $24(1), 1949,1-15$.

[5]. A. Kabata-Pendias and H. Pendias, Trace elements in soil and plants ( $2^{\text {nd }}$ edition. CRC Press. LLC, New York, 1997)

[6]. A. Mitra, K. Banerjee, and D. P. Bhattacharyya, The other face of mangroves (Department of Environment, Govt. of West Bengal, India 2004)

[7]. B. Gopal, and M. Chauhan, Biodiversity and its conservation in the Sundarbans mangrove ecosystem, Aquat. Sci., 68, 2006, 338354

[8]. C.Critchley, The role of chloride in Photosystem II, Biochim. Biophys. Acta. 811, 1985, 33-46

[9]. C.R. Hampson, G.M. Simpson, Effect of temperature, salt and osmotic potential on early growth of wheat Triticum sativum, I. Germination, Can. J. Bot. 68, 1990. 524-528

[10]. G. Agoramoorthy, Chen F-A and Hsu MJ. Threat of heavy metal pollution in halophytic and mangrove plants of Tamil Nadu, India, Environ Pollut. 155, 2008, 320-326.

[11]. G. Naidoo, A.V. Tuffers, D.J. Willert, Changes in gas exchange and chlorophyll fluorescence characteristics of two mangroves and one mangrove associate in response to salinity in natural environment, Trees-Structure and Function. 16, 2002, 140-146

[12]. G. R. Macfarlane and M. D. Burchett, Accumulation and partitioning of heavy metals in mangroves: A synthesis of field-based studies, Chemosphere 69, 2007, 1454-1464

[13]. G.A. Knox, and T. Miyabara, Coastal zone resource development and conservation in South East Asia, with special reference to Indonesia (UNESCO, Jakarta, Indonesia, 1984) 182

[14]. J.D. Barnes, L. Balaguer, E. Manrique, S. Elvira, A.W. Davison A reappraisal of the use of DMSO for the extraction and determination of chlorophylls $a$ and $b$ in lichens and higher plants, Env. Exp. Bot. 32(2), 1992, 85-100

[15]. K. Naskar and D. N. Guhabakshi, Mangrove swamps of Sunderbans, An ecological perspective, (Naya Prakash, Calcutta, India. 1987) 263

[16]. Lindsey H. Defew, James M. Mair , Hector M. Guzman, An assessment of metal contamination in mangrove sediments and leaves from Punta Mala Bay, Pacific Panama, Marine Pollution Bulletin, 50, 2005, 547-552

[17]. M.A Zidan, H.S. Al-Zahrani, Effect of $\mathrm{NaCl}$ on the germination Seedling and some metabolic changes in Sweet Basil (Ocimum basilicum). Pak. J. Sci. Ind. Res., 37, 1994, 541-543.

[18]. M. D. Burchett, C. D. Field, and A. Pulkownik, Salinity, growth and root respiration in the grey mangrove Avicennia marina Physiologia Plantarum, 60, 1984, 113-118.

[19]. M. Prica, B. Dalmacija, S. Roncevic, D. Kremar, M. Becelic, A comparison of sediment quality results with acid volatile sulphide (AVS) and simultaneously extracted metals (SEM) ratio in Vojvodina (Serbia) sediments. Science of Total Environment, 389, 2007, 235-244

[20]. Patrick D. Biber, Measuring the effects of salinity stress in the red mangrove, Rhizophora mangle L. International Greener Journals, 1(1), 2011, pp. 011-014

[21]. Peter, K. L. N., Sivasothi, N. A Guide to the Mangroves of Singapore I: The Ecosystem and Plant Diversity (Singapore Science Centre, 1999 ) 111-112

[22]. S. Dhanapackiam and M. H. Muhammad, Effect of salinity on chlorophyll and carbohydrate contents of Sesbania grandiflora seedlings, Indian Journal of Science and technology, 3 (1), 2010, 64-66

[23]. S. Hazra, T. Ghosh, R. Dasgupta, and G. Sen, Sea level and associated changes in Sundarbans, Science and Culture, 68, 2002. 309321

[24]. T.D. Sharkey, J.R. Seeman, J.A. Berry, Photosynthesis in intact Leaves of C3 Plants: Physics, physiology and rate limitations. Bot. Rev., 51, 1989, 53-105

[25]. V.J. Chapman, Wet coastal ecosystems (Elsevier, 1977) 428

[26]. V. Pahalawattaarachchi, C.S. Purushothoman and A. Vennila, Metal Phytoremediation Potential of Rhizophora mucronata (Lam.), Indian Journal of Marine Sciences, 38 (2), 2009, 178-183

[27]. W.E. Machado, V.Silva-Filho and RR. Oliveira, Trace metal retention in mangrove ecosystems in Guanabara Bay, SE Brazil. Mar Pollut Bull., 44, 2002, 1277-1280

[28]. W. J. S. Downton, Growth and osmotic relations of the mangrove Avicennia marina, as influenced by salinity. Australian Journal of Plant Physiology, 9, 1982, 519-528. 


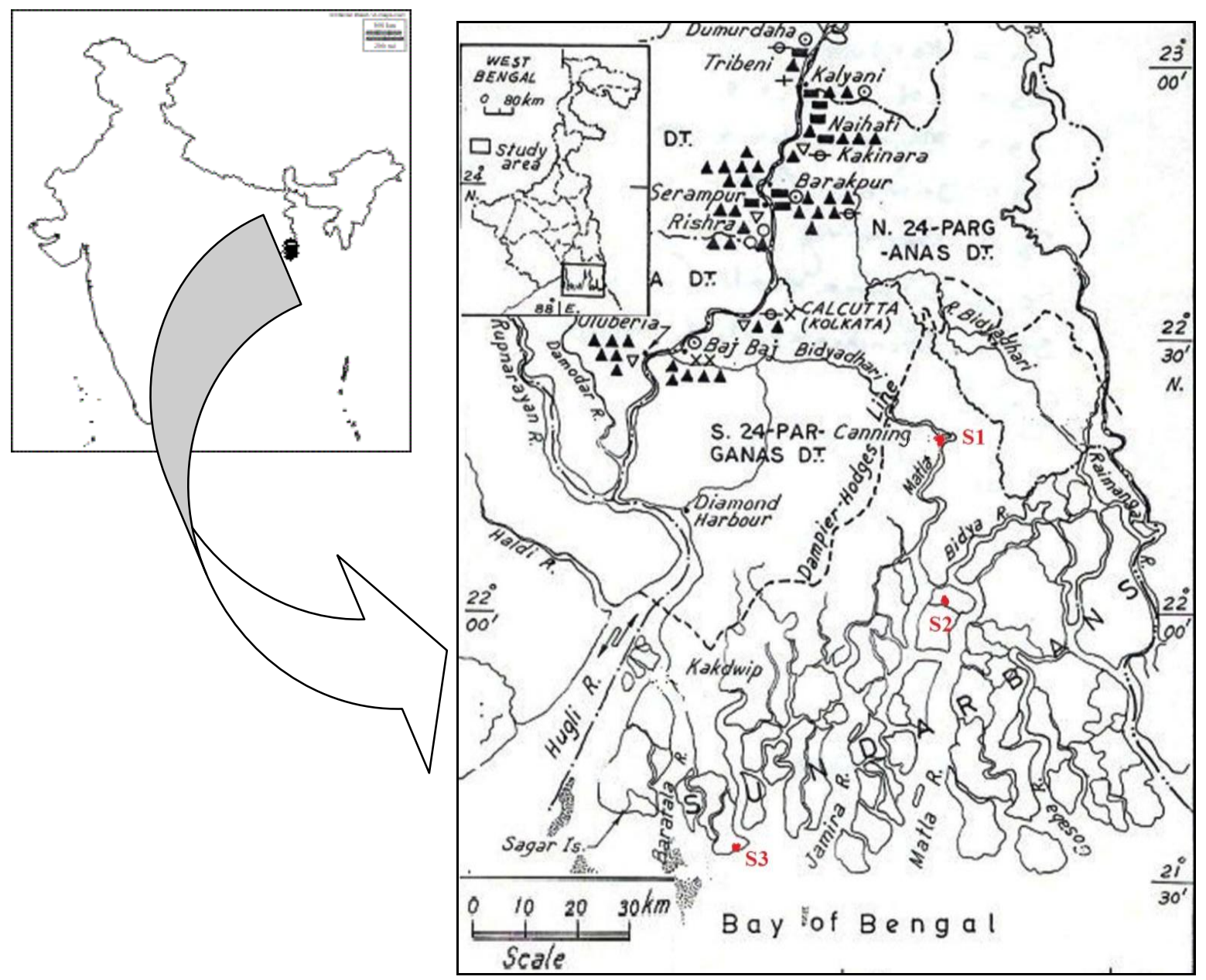

Figure1. Study area with three sampling sites [S1, S2 and S3]

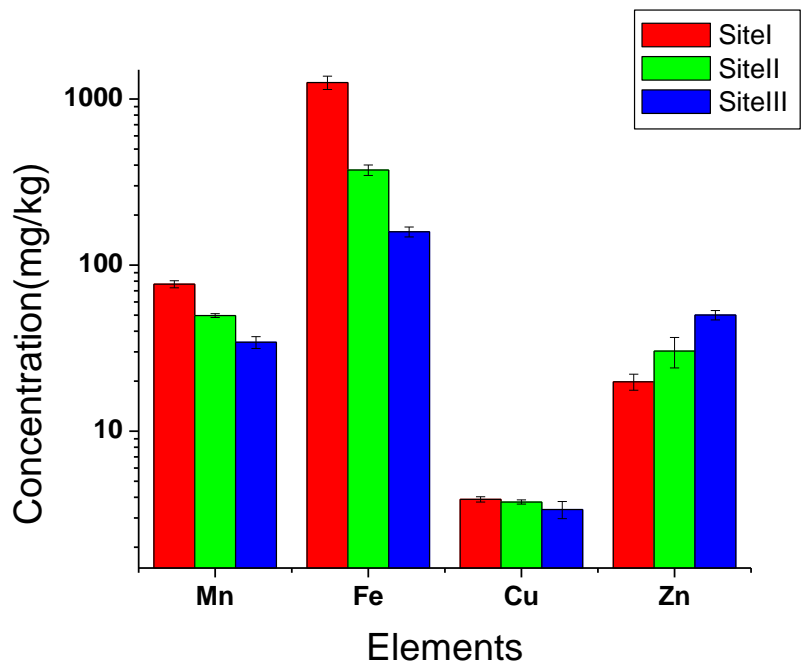

Figure2. Concentration of $\mathrm{Mn}, \mathrm{Fe}, \mathrm{Cu}$ and $\mathrm{Zn}$ in Excoecaria agallocha leaf in three specific sites 




Figure3. Concentration of Chlorophyll a, Chlorophyll b and Total Chlorophyll in Excoecaria agallocha in three specific sites

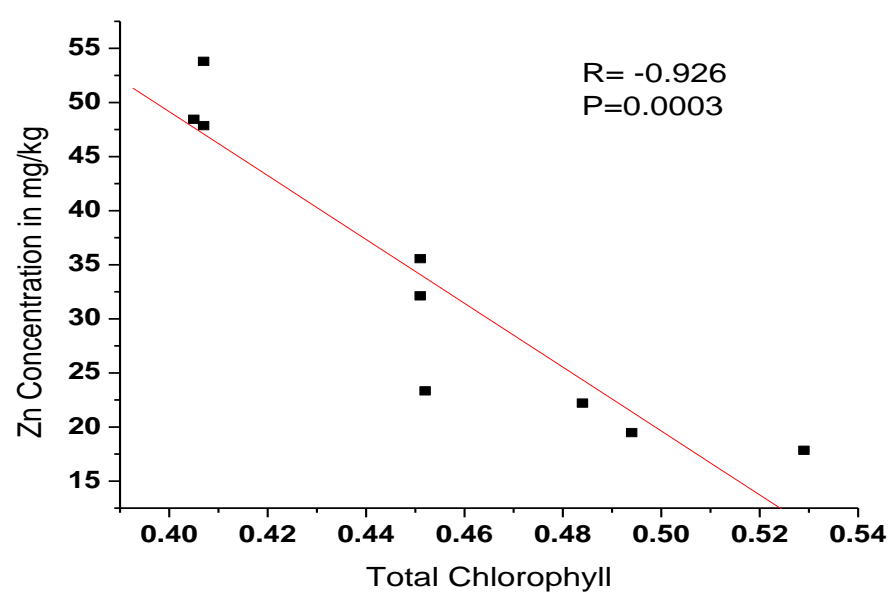

Figure3. Correlation between Total chlorophyll and Zinc



Figure4. Correlation between Total Chlorophyll and Water Salinity 


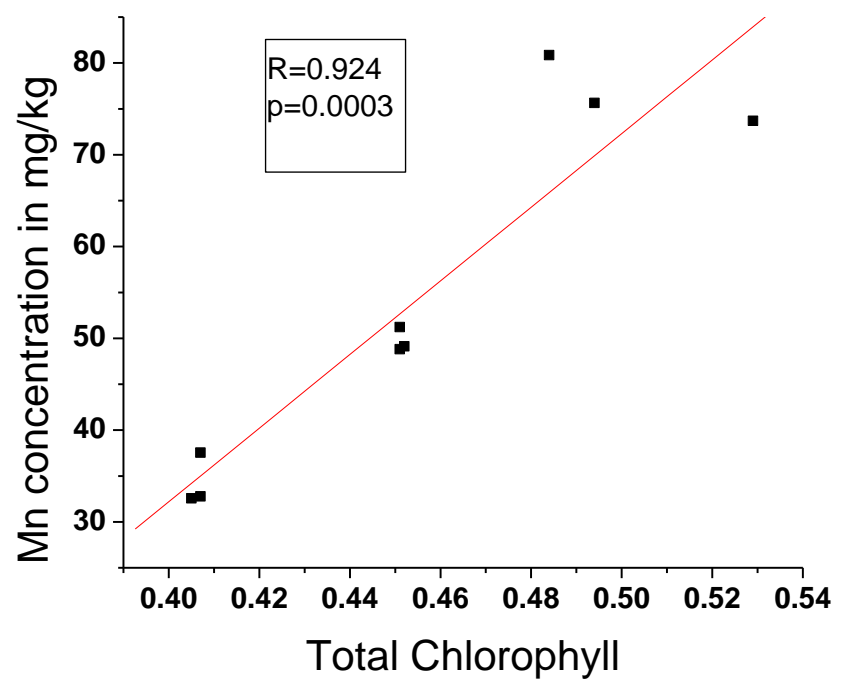

Figure5. Correlation between Total chlorophyll and Manganese

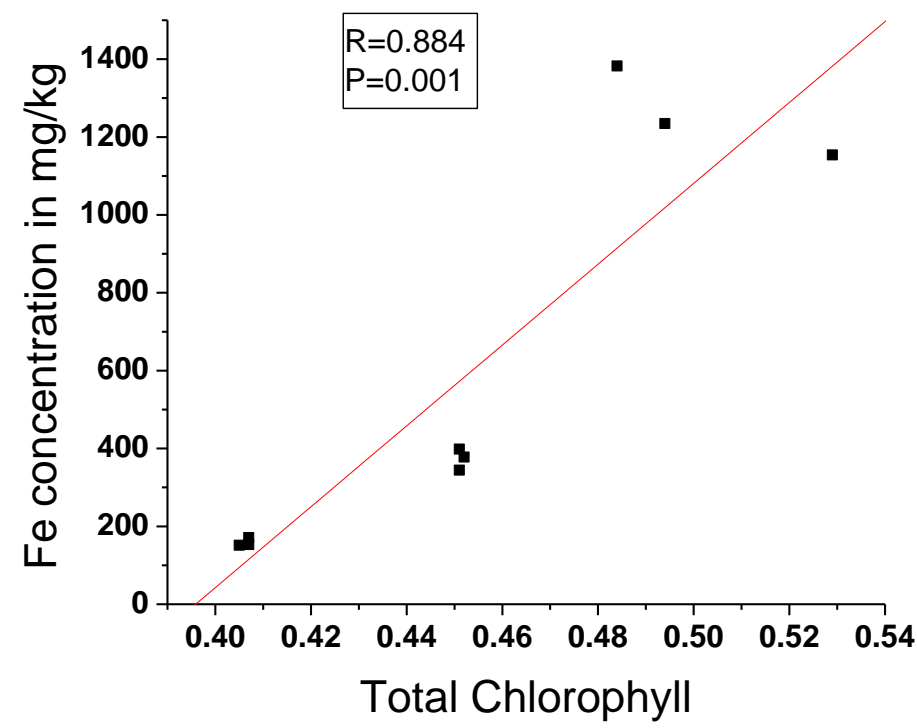

Figure5. Correlation between Total chlorophyll and Iron

\begin{tabular}{|c|l|l|}
\hline Name of The Study Area & \multicolumn{1}{|c|}{ Latitude \& Longitude } & \multicolumn{1}{|c|}{ Description } \\
\hline Site I (S1) & $22^{\circ} 18^{\prime} 40.5317^{\prime \prime} \mathrm{N} 88^{\circ} 40^{\prime} 31.2737^{\prime \prime} \mathrm{E}$ & $\begin{array}{l}\text { Highly populated area. Lots of } \\
\text { anthropogenic activity, fishing } \\
\text { activities, less saline }\end{array}$ \\
\hline Site II (S2) & $22^{\circ} 1^{\prime} 22.516^{\prime \prime} \mathrm{N} 88^{\circ} 41^{\prime} 11.7128^{\prime \prime} \mathrm{E}$ & $\begin{array}{l}\text { Less populated, fishing activities, } \\
\text { mangrove vegetation high, } \\
\text { moderately saline }\end{array}$ \\
\hline Site III (S3) & $21^{\circ} 34^{\prime} 25^{\prime \prime} \mathrm{N} 88^{\circ} 17^{\prime} 47^{\prime \prime} \mathrm{E}$ & $\begin{array}{l}\text { Less populated, High fishing } \\
\text { activities, mangrove vegetation } \\
\text { high, High saline }\end{array}$ \\
\hline
\end{tabular}

Table1. Description of the three sampling location of the study area 


\begin{tabular}{|l|r|r|r|r|r|r|r|c|}
\hline & \multicolumn{1}{|c|}{ Chla } & \multicolumn{1}{c|}{ Chlb } & Total Chl & \multicolumn{1}{c|}{ Mn } & Fe & \multicolumn{1}{c|}{ Cu } & Zn & Salinity \\
\hline Chla & 1 & & & & & & & \\
\hline Chlb & 0.938204 & 1 & & & & & & \\
\hline $\begin{array}{l}\text { Total } \\
\text { Chl }\end{array}$ & 0.9933 & 0.971912 & 1 & & & & & \\
\hline Mn & $0.950957 \mathrm{a}$ & 0.832484 & $0.924649^{\mathrm{a}}$ & 1 & & & & \\
\hline $\mathrm{Fe}$ & $0.913681 \mathrm{a}$ & 0.787888 & $0.884409 \mathrm{~b}$ & $0.981401 \mathrm{a}$ & & & & \\
\hline $\mathrm{Cu}$ & 0.620341 & 0.58815 & 0.618236 & 0.71482 & 0.628876 & 1 & & \\
\hline $\mathrm{Zn}$ & $-0.93934 \mathrm{a}$ & -0.86101 & $-0.92627 \mathrm{a}$ & -0.88147 & -0.82241 & -0.6036 & & 1 \\
\hline Salinity & $-0.9446 \mathrm{a}$ & -0.85859 & $-0.92904 \mathrm{a}$ & $-0.96558 \mathrm{a}$ & $0.97938 \mathrm{a}$ & 0.60921 & 0.856306 & \\
\hline
\end{tabular}

Table2. Correlation coefficients (Pearson) among chlorophyll-a, chlorophyll-b, total chlorophyll, water salinity and leaf elements of Excoecaria agallocha $[\mathrm{a}=\mathrm{p}<0.001, \mathrm{~b}=\mathrm{p}<0.05]$ 